\title{
BMJ Open Prison cell spatial density and infectious and communicable diseases: a systematic review
}

\author{
Paul L Simpson, ${ }^{\oplus 1}$ Melanie Simpson, ${ }^{\oplus 2}$ Armita Adily, ${ }^{1}$ Luke Grant, ${ }^{3}$ Tony Butler ${ }^{1}$
}

\begin{abstract}
To cite: Simpson PL, Simpson M, Adily A, et al. Prison cell spatial density and infectious and communicable diseases: a systematic review. BMJ Open 2019;9:e026806. doi:10.1136/ bmjopen-2018-026806

- Prepublication history and additional material for this paper are available online. To view these files, please visit the journal online (http://dx.doi. org/10.1136/bmjopen-2018026806).
\end{abstract}

Received 5 October 2018 Revised 9 April 2019 Accepted 13 June 2019

A Check for updates

(c) Author(s) (or their employer(s)) 2019. Re-use permitted under CC BY-NC. No commercial re-use. See rights and permissions. Published by BMJ.

${ }^{1}$ Kirby Institute, University of New South Wales, Sydney, New South Wales, Australia

2Juvenile Justice New South Wales, New South Wales Department of Justice, Sydney, New South Wales, Australia

${ }^{3}$ Corrective Services New

South Wales, New South Wales Department of Justice, Sydney, New South Wales, Australia

Correspondence to

Dr Paul L Simpson;

psimpson@kirby.unsw.edu.au

\section{ABSTRACT}

Objective To summarise the extent and quality of evidence on the association between prison cell spatial density (a measure of crowding) and infectious and communicable diseases transmission among prisoners. Design Systematic review.

Data sources Embase, PubMed, Medline, Scopus, Web of Science, PsycINFO, PsycExtra, ProQuest Databases, ProQuest Dissertations and Theses Global, Index to Legal Periodicals, InformitOnline, Cochrane Library, Criminal Justice Abstracts and ICONDA were searched to 31 December 2018.

Eligibility criteria Studies that reported on the association between prison cell spatial density (measured in square feet or square metres of cell floor area per person) and infectious and communicable diseases in juvenile and adult populations incarcerated in a correctional facility.

Data extraction and synthesis A review protocol was developed in consultation with an advisory panel. Two reviewers independently extracted data and used the Australian National Health and Medical Research Council's (NHMRC) checklist to critically appraise individual studies. An assessment of the overall body of the evidence was conducted using the NHMRC's Evidence Scale and Statement Form.

Results A total of 5126 articles were initially identified with seven included in the review from Pakistan (2003), Chile (2016), Nigeria $(2012,2013)$ and the USA (1980s). Infectious and communicable disease outcomes included pneumococcal disease/acute pneumonia, Mycobacterium tuberculosis, latent tuberculosis infection, infectious skin conditions and contagious disease reporting to the prison clinic. Five articles reported statistically significant positive associations but were countered by associations possibly being explained by chance, bias or confounding factors. Heterogeneity prevented meta-analysis.

Conclusion Overall, the body of evidence provides some support for an association between prison cell special density and infectious and communicable diseases, but care should be taken in the interpretation and transferability of the findings. Future research and policy responses should adequately consider prospective mediating factors implicated in associations between cell spatial density and health effects.

\section{INTRODUCTION}

Globally, the number of prisoners is increasing. Two per cent above world population growth, ${ }^{1}$ since the year 2000 , the world's prisoner population has grown by approximately

\section{Strengths and limitations of this study}

This is the first systematic review of the association between prison cell spatial density (a measure of crowding) and infectious and communicable diseases.

- We used an expert advisory panel to guide review protocols and the Australian National Health and Research Council frameworks to evaluate the strength and quality of the evidence.

- Most included studies had incomplete reporting of methodology and findings.

- This review was limited by the small number of studies in this area and the heterogeneity of study design.

$20 \%$, imposing a significant financial burden on society and having profound social and health consequences. ${ }^{2}$ More than 11 million people are held in penal institutions globally, either as remand (pretrial detainees) or convicted prisoners. Currently, 17 countries in the world have an incarceration rate of more than 400 per 100000 population in prison. USA is the largest incarcerator, accounting for approximately $20 \%$ of the world's prisoners with an incarceration rate of 655 per 100000 population. ${ }^{3}$

A rising prison population without a corresponding expansion of infrastructure has raised health concerns in many countries over prison crowding, ${ }^{3}$ making prison cell size a key public health issue. For example, in the Australian state of New South Wales (NSW), prison cell size as a public health issue emerged in recent times with the publication of the Inspector of Custodial Services report Full House: the growth of the inmate population in $\mathrm{NSW}^{4}$ the increase in the prisoner population, and the issue that a significant number of prison cells did not meet public health regulations on the minimum floor area requirements per prisoner. Historically, Corrective Services NSW had been exempted from such regulation provided a range of conditions imposed by the NSW Ministry of 
Health were met. In 2012, the Ministry required the NSW Department of Justice, Corrective Services to engage an independent (from Corrective Services) group to review the international literature on prison cell crowding and adverse health effects, a review of the international cell size guidelines, and a review of health surveillance data to advise the Ministers for Health and Justice.

Close physical proximity in confined spaces such as in prisons has been reported to be associated with an increased risk of infectious and communicable disease transmission including, Mycobacterium tuberculosis (MTB), scabies, pneumococcus, Meningococcus and influenza. ${ }^{5-7}$ Rates of infectious diseases in prisons, particularly bloodborne viral infections (HIV and viral hepatitis) and airborne infections such as MTB, are typically higher than in the general community which exacerbates the risk of disease transmission. ${ }^{689}$ Additionally, it has been suggested that the close physical proximity in prisons may induce psychological stress or intensify the existing stressful conditions in a prison ${ }^{10}{ }^{11}$ leading to alterations in immune and cardiovascular functions. ${ }^{12}$

The concept of crowding is understood in the academic literature and legislation as a mechanism that impacts adversely on the health and well-being of prisoners. Reports on prison conditions, prison standards and guidelines by international and regional agencies cite prison crowding as major health and human rights concerns impacting on this population. ${ }^{13-17}$ Left untreated in prison, the risk of disease transmission to family, friends, intimate partners and other community members is likely on leaving prison and returning to general society. ${ }^{18-22}$

Despite decades of research dedicated to prison conditions and its impact on health, there has been no systematic review to assess the quality of evidence of the association between prison crowding and infectious and communicable disease transmission. A lack of consensus exists on the best way to conceptualise and measure the essential element(s) of crowding with the debate centring on the need for objective versus subjective measurements of crowding. ${ }^{23}{ }^{24}$ The latter focuses on the individual experience or perception of crowding using subjective ratings of conditions such as behavioural constraints, stimulus and cognitive overload, privacy, desire to augment space and loss of environmental control. ${ }^{12526}$ The former, objective measures of prison crowding vary, but commonly revolve around metrics of prisoners per allocation of space to derive a measure of density (table 1 ).

Some of these measures have been criticised as being amenable to manipulation by prison authorities and thus regarded as invalid measures of prison crowding. ${ }^{24} 27$ Measures 4-10 (table 1) are regarded as objective measures of social and spatial density. Social density refers to the number of people in a defined area of the prison (eg, the whole facility, wing, dormitory or cell). Spatial density refers to the floor area of a defined area (eg, entire prison or cell) divided by the number of people in that space. ${ }^{11}$ Social and spatial densities are often dependent on one another, such as when the cell occupancy level increases,
Table 1 Objective prison crowding measures identified in the literature

\begin{tabular}{|c|c|}
\hline Measure & $\begin{array}{l}\text { Example of study } \\
\text { using measure }\end{array}$ \\
\hline $\begin{array}{l}\text { 1. Prisoner population divided by the } \\
\text { design capacity of the prison }\end{array}$ & $\begin{array}{l}\text { McCorkle et al, } \\
1995^{44}\end{array}$ \\
\hline $\begin{array}{l}\text { 2. Prisoner population divided by the } \\
\text { rated capacity of the prison }\end{array}$ & Tartaro, $2002^{45}$ \\
\hline $\begin{array}{l}\text { 3. Percentage of prison cells or } \\
\text { dormitories reported as overcrowded by } \\
\text { the institution }\end{array}$ & Anson, $1984^{46}$ \\
\hline $\begin{array}{l}\text { 4. Prisoner population divided by the } \\
\text { total no of available beds }\end{array}$ & $\begin{array}{l}\text { Bonta and Kiem, } \\
1978^{47}\end{array}$ \\
\hline 5. No of prisoners per prison & $\begin{array}{l}\text { Ruback and Carr, } \\
1984^{34}\end{array}$ \\
\hline $\begin{array}{l}\text { 6. No of prisoners per living space/cell } \\
\text { unit (including communal areas) }\end{array}$ & Atlas, $1982^{48}$ \\
\hline 7. No of prisoners per cell & $\begin{array}{l}\text { Urrego et al, } \\
2015^{49}\end{array}$ \\
\hline $\begin{array}{l}\text { 8. No of square metres of the total } \\
\text { prison floor area per person }\end{array}$ & $\begin{array}{l}\text { Ekland-Olson et al, } \\
1983^{50}\end{array}$ \\
\hline $\begin{array}{l}\text { 9. No of square metres of the total living } \\
\text { space/cell unit of the prisoner (including } \\
\text { communal areas) per person }\end{array}$ & Megargee, $1977^{51}$ \\
\hline $\begin{array}{l}\text { 10. No of square metres of the cell per } \\
\text { person }\end{array}$ & $\begin{array}{l}\text { McCain et al, } \\
1976^{52}\end{array}$ \\
\hline
\end{tabular}

this causes a corresponding increase in both social density and spatial density. In this review, the area (measured in square feet or square metres) of the cell per person was selected as the cell crowding measure and is referred to as cell spatial density. This measure was adopted for two reasons. First, the lack of consensus in the academic literature on the conceptualisation and measurement of crowding impressed the need to define cell crowding as an objectively defined environmental factor. Second, an examination of international guidelines on prison conditions and standards over the last half a century has seen a shift towards standards based on cell spatial density (see Simpson, Simpson and Butler, 2016). Cell spatial density as a metric has also entered the legislative domain such as in the Australian Capital Territory's Human Rights Act 2004 which recommends $8.9 \mathrm{~m}^{2}$ for single cells and $10.7 \mathrm{~m}^{2}$ for double cells. ${ }^{16}$

To determine the extent and quality of evidence on the association between prison cell crowding and health impacts, Kirby Institute researchers and authors (PLS, MS, AA and TB) were commissioned by the NSW Department of Justice, Correctives Services to conduct a systematic review of studies that analysed the association between prison cell spatial density and prisoner infectious and communicable diseases and mental health and well-being outcomes. In this paper, we present the results of our review of the association between cell spatial density and prisoner infectious and communicable disease effects, 
Table 2 Search terms used to identify evidence to inform the systematic review (example for PubMed database)

\begin{tabular}{|c|c|}
\hline & Academic databases \\
\hline $\begin{array}{l}\text { Search } \\
\text { terms }\end{array}$ & $\begin{array}{l}\text { prison OR 'corrective service*' OR 'correctional } \\
\text { cent*' OR 'correctional complex' OR } \\
\text { 'correctional facilit*' OR borstal OR jail }{ }^{\star} \text { OR } \\
\text { gaol* OR penitentiary OR 'detention cent*' OR } \\
\text { custody OR custodial OR 'closed setting*' AND } \\
\text { accommodation OR cell OR room OR cubicle } \\
\text { OR dormitory OR *crowding OR 'social density' } \\
\text { OR 'spatial density' AND health OR illness OR } \\
\text { sickn* OR infectio* OR transmissi OR disease* } \\
\text { OR hepatitis OR HIV OR tuberculosis OR parasite* } \\
\text { OR bacteria* OR virus OR viral OR influenz } \\
\text { OR gastroent* OR disorder OR depressi* OR } \\
\text { stress OR anxiety OR aggression OR irritability } \\
\text { OR violence OR self-harm OR suicide OR well- } \\
\text { being OR wellbeing AND prisoner OR inmate* } \\
\text { OR incarcerated OR criminal* OR felon* OR } \\
\text { remandee* OR delinquent* OR detainee* OR } \\
\text { convict* OR cellmate* }\end{array}$ \\
\hline
\end{tabular}

Targeted grey literature

$\begin{array}{ll}\text { Search } & \text { Prison cell and health effects, prison cell and } \\ \text { terms }^{*} & \text { health, jail cell and health, jail cell and health } \\ \text { effects, prison cell and health and size, jail cell and } \\ \text { health and size }\end{array}$

*Search terms varied according to website, only some examples are provided.

expressed in terms of the evidence of this association and the quality of the evidence.

\section{METHODS}

Under the direction of the NSW Ministry of Health and the NSW Department of Justice, an expert advisory panel was formed to guide the review comprising infectious diseases experts, public health professionals, academic staff and custodial administrators. A review protocol was developed following consultations with the advisory panel covering search strategy and selection criteria and study eligibility and appraisal. The Preferred Reporting Items for Systematic Reviews and Meta-Analyses guideline was adopted for the review. ${ }^{28}$

\section{Search strategy and selection criteria}

A search string was agreed to identify articles on the association between cell spatial density and infectious and communicable diseases and mental health outcomes (table 2). For the present paper, articles reporting on infectious and communicable disease outcomes were extracted from the final list of eligible studies. Reviews of the mental health outcome studies are reported elsewhere. ${ }^{29}$ Infectious and communicable diseases are defined 'as an illness due to a specific infectious agent or its toxic products that arises through transmission of such agent or products from an infected person, animal or reservoir to a susceptible host, either directly or indirectly through an intermediate plant or animal host, vector or inanimate environment'. ${ }^{30}$

The scope of the search was limited to the availability of an English abstract and to human subjects. Publication date was not restricted. Studies were excluded if they did not specify cell size or a measurement of cell spatial density, examined only temporary accommodation within custodial settings such as segregation cells, police cells, lockups, prison transport/transfer units and prison clinic accommodation. Studies examining combined living and sleeping space preventing the differentiation of sleeping space were also excluded from the current review.

Fourteen medical, social science and architectural databases were searched: EMBASE (1947-2018), PubMed $(\approx 1800-2018)$, Medline (1946-2018), Scopus (19762018), PsycINFO (1806-2018), PsycExtra (1908-2018), Web of Science (1900-2018), ProQuest Databases (17632018), ProQuest Dissertations and Theses Global (17162018), Index to Legal Periodicals (1985-2018), Informit Online (1920-2018), Cochrane Library ( $\approx 1900-2018)$, Criminal Justice Abstracts (1910-2018) and ICONDA (1976-2018). Grey literature was also identified from these database searches; and a further search for grey literature was conducted using Google and selected websites including those of the United Nations, International Committee of the Red Cross, Amnesty International, International Centre for Prison Studies, WHO, Campbell Collaboration, the Criminal Justice Reference Service, the US National Library of Medicine and websites of the Australian Inspector of Custodial Services. A number of international experts in the prisoner health area were contacted to inquire as to whether they were aware of additional material of potential interest to the review.

To manage records identified, articles were exported from databases into EndNote V.X7.1. Grey literature from non-database sources were entered into Endnote manually. PDF versions of articles were located and attached to Endnote items.

\section{Study eligibility}

All publications identified by the search were first screened by two independent teams of two reviewers (PLS, AA and MS, LG). To ensure consistency in the screening process and selection of eligible studies across the teams, titles and abstracts of the first 100 studies were independently reviewed by both teams and discussed as a group to ensure consistency. After achieving a consensus on eligibility for full-text review across both teams, the remaining articles were divided between the two teams of reviewers. Each person within the team independently reviewed their assigned literature, and on finishing, discussed the eligibility outcome with the other team member. In those instances where there was disagreement within a team, both teams met to resolve the issues and decide through consensus if the article was eligible for full-text review.

Articles were excluded from full-text review if the study design did not feature in the Australian National Health and Medical Research Council's (NHMRC) Hierarchy of 
Evidence. ${ }^{31}$ This hierarchy includes systematic reviews of prospective cohort studies (level I evidence), prospective cohort study (level II evidence), 'all or none' study (ie, either all or none of the people with the risk factor(s) experienced the outcome of interest) (level III-1 evidence) retrospective cohort study (level III-2 evidence), casecontrol study (level III-3 evidence), or cross-sectional study or case series (level IV evidence). ${ }^{31}$ Articles were also excluded if they did not conduct an analysis that examined the relationship between the exposure variable of prison cells accommodating one or more persons with a specified cell spatial density or cell dimensions and an outcome variable of an infectious and/or communicable disease.

\section{Critical appraisal of eligible studies}

Critical appraisal of eligible studies involved three stages: (1) data extraction, ${ }^{32}$ (2) assessment of bias, chance and confounding $^{33}$ and (3) an aggregated assessment of all studies using the NHMRC FORM Matrix and Evidence Statement to produce a final rating and evidence statement. $^{31}$

An adapted version of the NHMRC's standardised data summary table was used to extract data. ${ }^{32}$ Data extraction tables were prepared and cross-checked by two independent reviewers (PLS and MS). Extracted information included: general study details (citation, study design, length of follow-up, level of evidence and location and setting); study exposure and control descriptions; population characteristics; internal and external validity considerations; and study outcomes and results.

Assessment of bias, chance and confounding was guided by the NHMRC's checklist to critically appraise aetiology or risk factor studies. ${ }^{33}$ Checklist items used to guide the assessment of studies included: exposure misclassification, outcome misclassification, selection bias, confounding and chance. Items were assessed on one of two 3-point scales: low (0), medium (1), high (2) risk; or poor (0), fair (1), good (2).

A systematic assessment of the overall body of the evidence was conducted using a modified (for study population relevance) NHMRC FORM Matrix and Evidence Statement covering ${ }^{34}$ : (1) evidence base, (2) consistency of results, (3) population health impact and (4) generalisability. Each component was rated from excellent to poor (online supplementary appendx A) to allow a final overall rating and evidence statement to be derived ranging from 'A' to D': 'A' indicating that the body of evidence can be trusted to ' $\mathrm{D}$ ' indicating that the body of evidence is weak, and findings cannot be trusted (online supplementary appendx B).$^{31}$ The final overall rating and evidence statement were undertaken by one reviewer (PLS) and crosschecked by another (MS).

Following the completion of the review by the team, an expert, independent of the reviewers and advisory panel, peer reviewed the methodology and findings.
Patient and public involvement

Patients and the public were not involved in the review.

\section{RESULTS}

After removing duplicate records and newspaper and magazine articles, a total of 5126 records were assessed for eligibility based on publication title and abstract content (figure 1). As a result of this screening, 41 records that reported on infectious and communicable diseases and/ or mental health outcomes were identified for full-text review. For the present review, seven publications met the inclusion criteria for infectious and communicable disease outcomes; five articles were published in peer-reviewed journals ${ }^{35-39}$ and two were reports. ${ }^{27} 40$ Two articles related to the same research programme on prison crowding ${ }^{2740}$; two articles derived from the same study on infectious skin conditions. ${ }^{37} 38$ Five articles examined the association between cell spatial density and pneumococcal disease or acute pneumonia, ${ }^{35} \mathrm{MTB},{ }^{36}$ latent tuberculosis infection (LTBI) ${ }^{39}$ and infectious skin conditions, ${ }^{37} 38$ respectively, while two articles reported on communicable illness presentation to the prison clinic. ${ }^{27} 39$ Three studies were conducted in the USA, ${ }^{2735}{ }^{40}$ two in Nigeria, ${ }^{37} 38$ one in Chile ${ }^{39}$ and one in Pakistan (table 3) ${ }^{36}$ Meta-analysis was not possible due to heterogeneity and incomplete reporting of findings. Measures of effect reported in the six publications varied and included OR, risk ratio, and mean and group differences.

Six studies were cross-sectional in design (level IV aetiology evidence) and one included both a case-control and cohort study design reported in the same article (level III-3/III-2 aetiology evidence). Outcome measures for the pneumococcal disease ${ }^{35}$ and $\mathrm{MTB}^{36}$ studies were measured using a standardised and reliable approach (tuberculin sensitivity test using the Mantoux method, culture from blood, pleural or spinal fluid specimen and radiograph). LTBI was measured using interferon-gamma release assays (IGRAs) and those found to be IGRA positive underwent direct sputum smear microscopy and chest radiography to diagnose active TB or LTBI. ${ }^{39}$ Two articles measured infectious skin conditions ${ }^{37} 38$ 'in part' in a standardised and reliable way (clinical examination of the body by a consultant dermatologist and venereologist). The validity and reliability of the outcome measure for the two studies examining communicable illness presentations to a prison clinic 2740 were deemed poor. This is because presentations to a prison clinic may additionally capture other parameters of health service use besides and beyond health effects such as, dispositional characteristics of prisoners and the administration of medical care in the prison. ${ }^{40}$

Although the sampling framework was described well in most studies, the sampling method was absent in two articles ${ }^{37} 38$ and response rates were not reported in four articles. ${ }^{27} 373840$ Self-report measures were used in six studies to determine potential confounders such as underlying medical conditions and demographic 


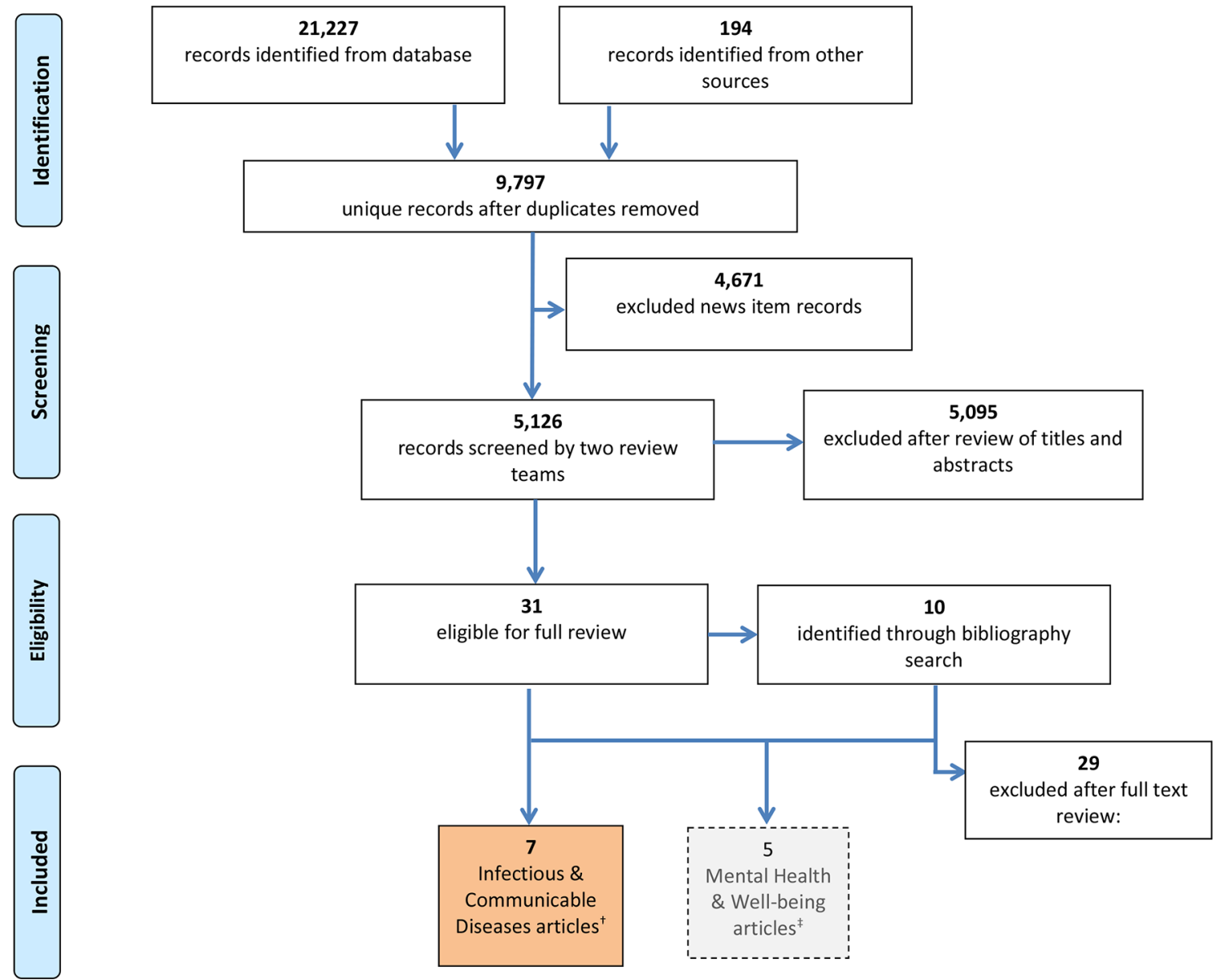

Figure 1 Flow chart for selection of articles.

information, therefore, recall bias is a possibility. With the exception of the case-control and cohort studies (casecontrol: $\mathrm{n}=25$ cases $/ 75$ controls; cohort: $\mathrm{n}=46),{ }^{35}$ sample sizes were relatively similar across the five cross-sectional studies $(n=289-428)$. Four studies considered or adjusted for confounding factors or effect modifiers in the analyses $^{27} 363940$; two studies did not, ${ }^{37} 38$ and it is unclear whether multivariate analysis was conducted in one study. ${ }^{35}$

\section{Evidence of an association between cell spatial density and infectious and communicable diseases}

While the review found mostly consistent evidence that cell spatial density is associated with clinically verifiable infectious and communicable diseases, with five articles reporting a statistically significant association between cell spatial density and infectious and communicable diseases (table 3), all but one of these associations could possibly be explained by chance, study bias or confounding.

In the study which investigated MTB infection in a random sample of 425 male prisoners in five Pakistan prisons, the association between cell spatial density and MTB was reported to be statistically significant (adjusted OR (aOR) 2.6; 95\% CI 1.6 to 4.3) after adjusting for age, education, length of incarceration, tobacco use and other variables. ${ }^{36}$ However, caution is warranted when interpreting this result due to possible exposure and outcome misclassification. That is, the cell spatial density measure was a dichotomised average floor area per person (ie, $>5.6 \mathrm{~m}^{2}$ per person and $\leq 5.6 \mathrm{~m}^{2}$ per person) and thus may be a crude measure. The study does not report on how this measure was determined. Additionally, the $100 \%$ response rate to the screening suggests possible coercion to participate in the study that may have affected the reliability of self-report data ta (eg, household income, occupation).

The LTBI study was conducted in 46 prisons in Chile and included 418 prisoner and non-prisoner contacts of 33 active TB cases recruited 12 months following the identification of active TB cases. ${ }^{39}$ The study found high TB incidence (123.9 per 100000 prisoners) and high LTBI prevalence (29.4\%) among contacts, with LTBI rates significantly higher in prisoners than in non-prisoners $(33.2 \%$ vs $15.6 \%)$. Multivariate analyses showed a significant association between cell spatial density and LTBI (aOR 3.5; 95\% CI 1.1 to 11.5) after adjusting for gender, age, illicit drug use, history of corticosteroid use and malnutrition, and length of incarceration. Assessing the extent of potential exposure misclassification was difficult as the spatial density measure used in analysis is not reported (unclear if continuous or categorical variable used). Cell type (ie, multiple-person cells, dormitories) across the different prisons was also not reported. 


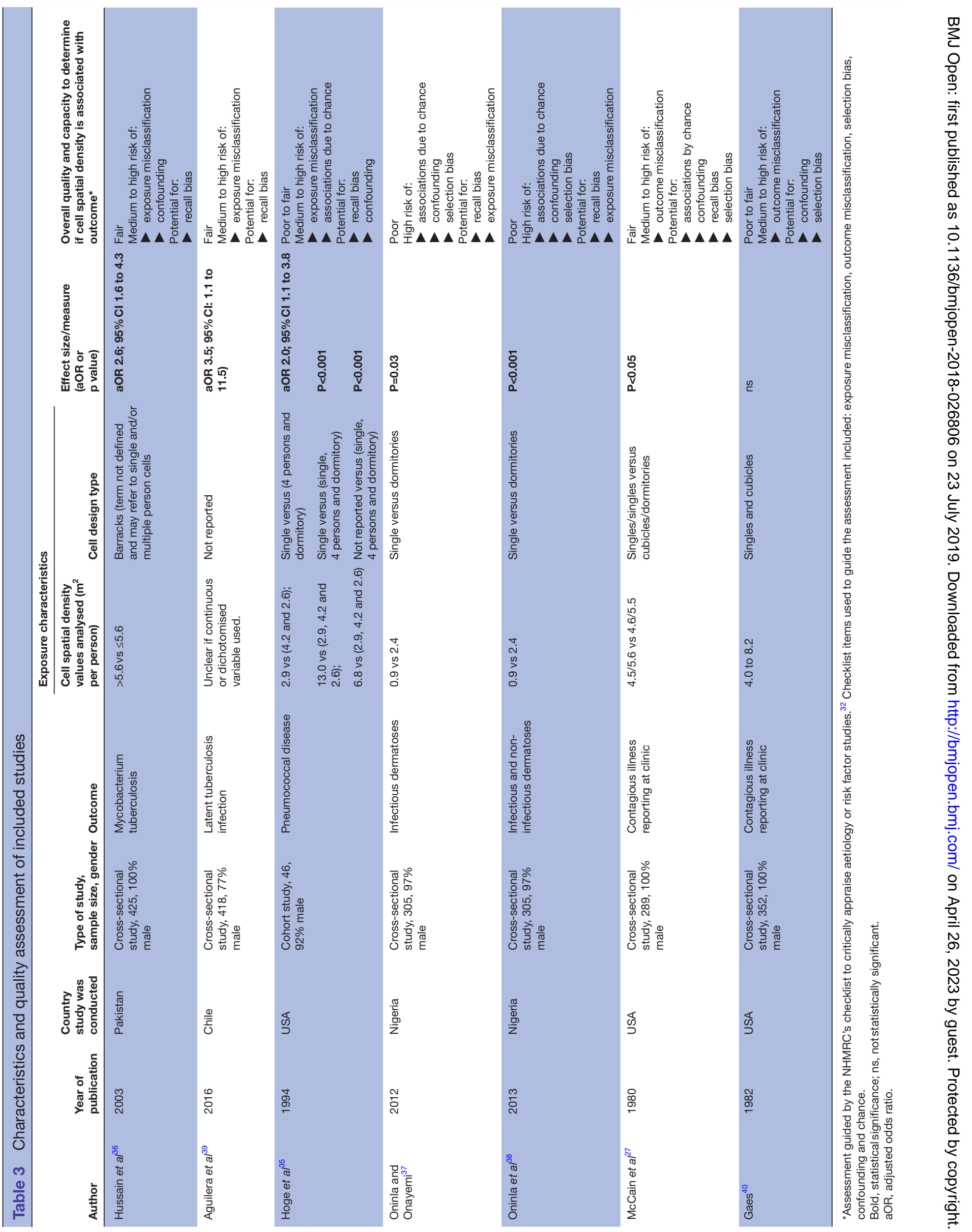


One US study investigating a pneumococcal disease outbreak $^{35}$ examined the disease attack rate and its association with cell spatial density. Although more clarity and consistency in reporting of the analysis is needed to properly assess the findings, the results indicate that the attack rate was highest in four-person cells $\left(2.9 \mathrm{~m}^{2}\right.$ per person) compared with the two other cell types described (single cells at $4.2 \mathrm{~m}^{2}$ per person and open dormitories at $2.6 \mathrm{~m}^{2}$ per person). The study also reported that detainees housed in shared and single areas $\geq 7.4 \mathrm{~m}^{2}$ per person $(8 \%$ of the inmate population) had significantly fewer cases of pneumococcal disease than all other detainees (attack rate: 0 vs 4.7 per 1000 persons; $p=0.03$ ). This lower attack rate for detainees housed in shared areas $\geq 7.4 \mathrm{~m}^{2}$ per person may in part be explained by time spent outside cells as those housed in this area were engaged in work programmes and left their cells to undertake such work. Results were inconsistently reported across cell types with both univariate and aORs reported for the different cell types suggesting that some results were adjusted for and some not.

In the two studies conducted with mostly male $(97 \%)$ prisoners in Nigeria, the prevalence of infectious and non-infectious skin conditions among prisoners living in single cells $\left(0.9 \mathrm{~m}^{2}\right.$ per person $)$ and dormitories $\left(2.4 \mathrm{~m}^{2}\right.$ per person) was significantly different at $61.7 \%$ vs $43.2 \%^{37}$ and $82.9 \%$ vs $69.7 \% .{ }^{37}{ }^{38}$ However, the quality for these studies was assessed as 'poor' due to the absence of any multivariate analysis, no details of whether those conducting the physical examinations were blinded to the cell assignments of the prisoners, no response rates or sampling method described, and cell type details derived from self-report questionnaires.

Two other US articles reporting on the association between cell spatial density and illness reporting at the prison clinic were from a research programme spanning approximately 10 years reporting on data collected from 1400 prisoners from six federal prisons. ${ }^{27}{ }^{40}$ Illness reporting rates were determined by dividing the number of days a participant was in a cell type (with a specific cell social or spatial density) by the number of visits to a clinic. Not all outcomes were measured at and/or reported for all prison sites, and prisoner population characteristics, sampling methods, response rates and analytical procedures are not consistently reported across and within publications. One article, the Danbury prison study, reported results on illness reporting by contagious status, ${ }^{27}$ covering: venereal disease; eye, ear, nose, throat infections; cough, cold, influenza; gastrointestinal, stomach problems; skin conditions; virus; chills and fever. However, the lack of detail on the statistical analysis means it is unclear if potential confounders and effect modifiers were adjusted for. Nonetheless, the findings reported a significant difference (although $\mathrm{p}$ values were not reported) in contagious illness reporting between those in single occupant cells of 4.5 and/or $5.6 \mathrm{~m}^{2}$ per person ( 0.03 reports per week) and those in dormitories with a spatial density of 4.6 and/or $5.5 \mathrm{~m}^{2}$ (0.06 reports per week) per person. As the reported cell spatial area range of these two cell types are nearly identical, this is likely to say more about the effect of social density (the number of individuals per cell) or cell type (dormitories vs singles) than it does on cell spatial density.

The second US study from this research examined cell spatial density in single occupancy cells alone in two federal prisons. ${ }^{40}$ Using multiple linear regression analysis, statistically significant effects were reported in only one of the prisons. However, for contagious illness, the cell spatial density variable was reported as not significant $(\mathrm{p}=0.88)$. However, the validity and reliability of the outcome measure used are questionable as the measure may capture other parameters of health service use besides health effects.

\section{DISCUSSION}

Despite the attention that prison crowding receives, this review identified only seven articles examining cell spatial density and infectious and communicable diseases. While the methodological approach adopted in this review ensured that the largest number of peer-reviewed and grey literature publications were identified, some studies and outcomes may have been missed due to publication and outcome reporting bias. Some journals may be more likely to publish studies that report statistically significant results and overlook studies that are not consistent with previously published studies, present 'negative data' that disproves the investigators' hypothesis, as well results that could be interpreted to be of little interest or relevance to their readership. ${ }^{41}$ Due to the difficulty in locating study protocols, assessment of selective reporting of outcomes was not conducted. Thus, outcome reporting bias may also be present.

The identified seven studies were conducted with mostly male prisoner populations in the USA, Pakistan, Chile and Nigeria. Infectious and communicable disease outcomes reported included pneumococcal disease, MTB, LTBI, skin conditions and prisoner reporting of communicable illness to the prison clinic. Six were cross-sectional studies and one was a combined case-control and cohort study.

Overall, the evidence concerning the association between prison cell spatial density and infectious and communicable disease effects was given a rating of ' $\mathrm{C}$ ' on the NHMRC Evidence Rating Scale (ranging from 'A' to 'D') indicating that 'the body of evidence provides some support for an association between cell spatial density and infectious and communicable diseases but care should be taken in the interpretation of the findings. ${ }^{31}$ The review found that there was mostly consistent evidence that cell spatial density is associated with clinically verifiable infectious and communicable diseases. Although five of the seven studies reported a statistically significant positive association between cell spatial density and infectious and communicable disease effects (one additional study reporting a significant association regarding the effect of social density or cell type rather than cell spatial density), 
the quality of the studies was assessed as poor due to risk of exposure/outcome misclassification, bias, chance and/or confounding. However, the Pakistan study on $\mathrm{MTB}^{36}$ and the Chile Study on $\mathrm{LTBI}^{39}$ adjusted for potential confounders and chance.

The cross-sectional design of six of these studies means the ability to assess causality is limited in that they were carried out at one given point in time and provide no indication of the sequence of events. As such, it remains unclear whether cell spatial density exposure preceded or followed the onset of infectious or communicable diseases reported in these studies. However, one study provided some evidence that a number of infections occurred inside prisons following a repeat testing performed at 8 weeks after baseline, suggesting cell spatial density exposure contributed to these new infections. ${ }^{39}$ The associations and statistical precision observed in the articles suggest the possibility of a 'slight' health impact of cell spatial density on prisoners in regard to infectious diseases. However, it is possible that these associations are due to confounding, bias and/or chance. In addition, differences between the populations examined in these studies were apparent in terms of socio-cultural demographics, institutional settings and practices, and the background prevalence of infectious and communicable diseases outcomes in the respective countries (USA, Nigeria, Pakistan, Chile). Studies were also conducted in different decades. These apparent differences restrict the generalisability and transferability of the observed effects to correctional contexts outside the countries where the reviewed studies were conducted.

\section{Implications for researchers and policy-makers}

Further research is needed that addresses the confounding, bias and chance elements in studies examined by this review. We recommend that future studies include clinically verifiable health outcomes to ensure outcome misclassification is prevented or minimised and include adequate detail on how cell floor spatial density was determined to facilitate a clear assessment of exposure misclassification.

In most articles reviewed, inadequate attempts were made to adjust for personal characteristics of prisoners and/or prison-related factors as potential confounders. This statement acknowledges that cell spatial density, as an objective condition of crowding, is likely to be embedded in a complex interplay of psychological, social, cultural and institutional factors, and that variations of any health effects cannot be fully understood without their consideration. Thus, future research should seek to collect more extensive data on prospective confounding and mediating factors to examine how such factors interact with cell spatial density and health effects. To assist this, we reviewed the 12 eligible articles identified in this review (7) and the mental health and well-being review (5), ${ }^{29}$ in addition to key international reports on prisoner conditions, prison crowding and prisoner health to identify what factors might mediate the association between prison cell spatial density and adverse health effects. ${ }^{42}$ From this review, we recommend that future research on cell spatial density and health effects consider the following factors: (1) personal characteristics of prisoners such as age, education level, gender, ethnicity, underlying medical conditions and health risk behaviours (eg, current intravenous drug use); (2) physical environment measures such as air ventilation and privacy afforded to the prisoner and (3) social and policy environment of prison such as time confined in cell per day, cell allocation policy and practice, health service access, length of incarceration and custody and security classification of prisoner. $^{42}$

Although the body of evidence assessed indicated cautious support for the association between prison cell spatial density and infectious and communicable diseases, we do not advocate increasing social and spatial density and there is likely to be reasonable grounds for policy responses to address prison crowding in the absence of scientific certainty. As one US Court of Appeals ${ }^{43}$ ruling stated:

Undoubtedly, certainty is the scientific ideal-to the extent that even science can be certain of its truth. But certainty in the complexities of environmental medicine may be achievable only after the fact, when scientists have the opportunity for leisurely and isolated scrutiny of an entire mechanism. Awaiting certainty will often allow for only reactive, not preventive regulation.

In the absence of scientific certainty, international standards and recommendations provide guidance by way of mitigating prison and prison cell crowding and any potential infectious and communicable disease effects this may bring. The International Red Cross Association (ICPA) handbook on Water, Sanitation, Hygiene and Habitat in Prisons recognises that any technical focus on prisons to address potential adverse health effects, such as cell spatial density, cannot be separated from addressing other factors that mediate prisoner health and wellbeing. ${ }^{17}$ Some ICPA guidelines and recommendations are feasible in terms of implementation in the short term to address immediate need (eg, access to healthcare and sanitary facilities and extending time 'out-of-cell' to participate in meaningful activities). A public health approach to addressing any adverse health effects associated with prison cell crowding should include prevention strategies ranging from the micro to the macrolevel. The United Nations' Office of Drugs and Crime Handbook on Strategies to Reduce Overcrowding in Prisons ${ }^{13}$ acknowledges that to address the health effects associated with crowding, 'decarceration' strategies to prevent prison crowding occurring in the first instance is required. Decarceration strategies involve processes that remove people from prisons and prevent them from (re)entering prison. This is likely to be a longer term strategy that will require extensive work involving multiple agencies from 
different sectors, and changes in political and societal attitudes to incarceration.

Acknowledgements We would like to acknowledge advisory panel members Wayne Smith and Benjamin Scalley of the New South Wales Ministry of Health; Garry Forrest and Denise Monkley of the Justice Health and Forensic Mental Health Network; and Janaya Ho of Corrective Services New South Wales. We would also like to acknowledge the independent peer review undertaken by Jeffrey Post and Lorraine Yap and Marina Talevski with respect to their contributions to this review.

Contributors PLS is the guarantor. PLS, MS, AA and TB drafted the manuscript. All authors contributed to the development of the selection criteria. PLS, MS and TB contributed to the risk of bias assessment strategy, data extraction templates and developed the search strategies. All authors read, provided feedback and approved the final manuscript.

Funding Under the direction of the New South Wales Ministry of Health, the New South Wales Department of Justice funded this review. To ensure appropriate management of perceived or potential conflicts of interest, the expert advisory panel that was formed to guide the review comprised diverse stakeholders, including medical practitioners, infectious diseases experts, public health professionals, a custodial administrator and academic staff. Author and custodial administrator LG, who although contributed to the scope of the search criteria and provided feedback and approval of the final manuscript, did not contribute to data extraction, confounder, bias and chance assessment, aggregated evidence appraisal and ratings and the interpretation of findings.

Competing interests There was grant support from the New South Wales Department of Justice during the conduct of the study. There are no financial relationships with any other organisations that might have an interest in the submitted work in the previous 3 years. Author $L G$ is a custodial administrator and could give the appearance of potentially influencing findings. Although $L G$ contributed to the scope of the search criteria and provided feedback and approval of the final manuscript, he did not contribute to data extraction, confounder, bias and chance assessment, aggregated evidence appraisal and ratings and the interpretation of findings. At the time of the review, MS was employed as a research associate of the Kirby Institute, University of New South Wales, Sydney.

Patient consent for publication Not required.

Ethics approval Ethics approval was not required. Please see 'Ethical approval for literature reviews and meta-analyses' on the UNSW Sydney Research Ethics \& Compliance Support Frequently Asked Questions (FAQs) page (https://research. unsw.edu.au/frequently-asked-questions-faqs).

Provenance and peer review Not commissioned; externally peer reviewed.

Data sharing statement № additional data are available.

Open access This is an open access article distributed in accordance with the Creative Commons Attribution Non Commercial (CC BY-NC 4.0) license, which permits others to distribute, remix, adapt, build upon this work non-commercially, and license their derivative works on different terms, provided the original work is properly cited, appropriate credit is given, any changes made indicated, and the use is non-commercial. See: http://creativecommons.org/licenses/by-nc/4.0/.

\section{REFERENCES}

1. United Nations. United Nations, Department of Economic and Social Affairs, Population Division. New York: World Population Prospects: The 2018 Revision, 2018.

2. Huber A, Rope O, Sheahan S. Global Prison Trends 2017. London: Penal Reform International, 2017.

3. Walmsley R. World Prison Population List. 12th edn: Institute for Criminal Policy Research, 2018.

4. New South Wales Department of Justice Inspector of Custodial Services. The growth of the inmate population in NSW. Sydney: NSW Government, 2015.

5. Walker B, Gordon T. Health and high-density confinement in jails and prisons. Federal Probation 1980;44:53-7.

6. Walker B. Prison population pressures: the epidemiological basis for present density standards. Journal of Environmental Health 1991;54:18-20.

7. European Centre for Disease Prevention and Control. Systematic review on active case finding of communicable diseases in prison settings. Stockholm: European Centre for Disease Prevention and
Control and the European Monitoring Centre for Drugs and Drug Addiction, 2017.

8. New York State Commission of Correction. Examination of density and crowding in correctional facilities and their applicability to the question of double-celling. New York, USA: New York State Commission of Correction, 1981.

9. UNAIDS. UNAIDS Technical Update Prisons and AIDS Geneva: Joint United Nations Programme on HIV/AIDS. 1997.

10. Gaes GG. Effects of Overcrowding in Prison. In: Tonry M, Morris $\mathrm{N}$, eds. Crime and justice volume 6: an annual review of research. Chicago, USA: The University of Chicago Press, 1985:6. 95-146.

11. Paulus PB. Prison crowding: a psychological perspective. New York: Springer-Verlag, 1988.

12. Cox VC, Paulus PB, McCain G. Prison crowding research: the relevance for prison housing standards and a general approach regarding crowding phenomena. Am Psychol 1984;39:1148-60.

13. United Nations Office on Drugs and Crime. Handbook on strategies to reduce overcrowding in prisons. Vienna: United Nations Office on Drugs and Crime, 2010.

14. United Nations Office on Drugs and Crime. The United Nations Standard Minimum Rules for the Treatment of Prisoners ('the Mandela Rules'). Geneva: United Nations, 2015.

15. European Committee for the Prevention of Torture and Inhuman or Degrading Treatment or Punishment. European Committee for the Prevention of Torture and Inhuman or Degrading Treatment or Punishment (CPT): CPT Standards. Strasbourg Cedex, France: Council of Europe, 2015.

16. International Committee of the Red Cross. Review of space accommodation standards in prison cells. Geneva: International Committee of the Red Cross, 2014.

17. International Committee of the Red Cross. Water, sanitation, hygiene and habitat in prisons: supplementary guidance. Geneva, Switzerland: International Committee of the Red Cross, 2012.

18. Farmer PE, Kononets AS, Borisov SE. Recrudescent tuberculosis in the Russian Federation. In: Farmer PE, Reichman LB, Iseman MD, eds. The global impact of drug resistant tuberculosis. Boston, MA: Harvard Medical School/Open Society Institute, 1999.

19. Greifinger RB. Inmates as public health sentinels prison reform: commission on safety and abuse in America's Prisons. Journal of Law and Policy 2006;22:253-64.

20. Shilova MV, Dye C. The resurgence of tuberculosis in Russia. Philos Trans R Soc Lond B Biol Sci 2001;356:1069-75.

21. Stern V. The Problems of TB in Prisons in Eastern Europe and Central Asia. London: International Centre for Prison Studies, 1999.

22. Restum ZG, Zulficar GR. Public health implications of substandard correctional health care. Am J Public Health 2005;95:1689-91.

23. Gaes GG. Prison Crowding Research Reexamined. Prison $J$ 1994;74:329-63.

24. Ostfeld AM, KasI SV, D'Atri DA, et al. Stress, crowding, and blood pressure in prison. New Jersey: Lawrence Erlbaum Associates, 1987.

25. Schmidt DE, Keating JP. Human crowding and personal control: an integration of the research. Psychol Bull 1979;86:680-700.

26. Stokols D. Environmental psychology. Annu Rev Psychol 1978;29:253-95.

27. McCain G, Cox VC, Paulus PB. The effect of prison crowding on inmate behavior. Washington DC: National Institute of Justice, 1980.

28. Moher D, Liberati A, Tetzlaff J, et al. Preferred reporting items for systematic reviews and meta-analyses: the PRISMA statement. Int $J$ Surg 2010;8:336-41.

29. Simpson PL, Simpson M, Butler T. Prison cell size and adverse health effects: a systematic review. Sydney: The Kirby Institute, UNSW Australia and Corrective Services NSW, 2016. (ISBN-10: 0-73343615-3; ISBN-13: 978-0-7334-3615-4).

30. Porta M, ed. A dictionary of epidemiology. 6th edn. New York: Oxford University Press, 2014.

31. National Health and Medical Research Council. NHMRC Additional Levels of Evidence and Grades for Recommendations for Developers of Guidelines. Canberra, ACT, Australia: National Health and Medical Research Council, 2009.

32. National Health and Medical Research Council. NHMRC Standards and procedures for externally developed guidelines. Canberra, ACT, Australia: National Health and Medical Research Council, 2007.

33. National Health and Medical Research Council. How to review the evidence: systematic identification and review of the scientific literature. Canberra: National Health and Medical Research Council, 2000.

34. Ruback RB, Carr TS. Crowding in a Woman's Prison: attitudinal and behavioral effects1. J App/ Soc Psychol 1984;14:57-68.

35. Hoge CW, Reichler MR, Dominguez EA, et al. An epidemic of pneumococcal disease in an overcrowded, inadequately ventilated jail. N Engl J Med 1994;331:643-8. 
36. Hussain H, Akhtar S, Nanan D. Prevalence of and risk factors associated with mycobacterium tuberculosis infection in prisoners, North West Frontier Province, Pakistan. Int J Epidemiol 2003;32:794-9.

37. Oninla OA, Onayemi O. Skin infections and infestations in prison inmates. Int J Dermatol 2012;51:178-81.

38. Oninla OA, Onayemi O, Olasode OA, et al. Pattern of dermatoses among inmates of llesha Prison, Nigeria. Niger Postgrad Med $\mathrm{J}$ 2013;20:174-80.

39. Aguilera XP, González C, Nájera-De Ferrari M, et al. Tuberculosis in prisoners and their contacts in Chile: estimating incidence and latent infection. Int J Tuberc Lung Dis 2016;20:63-70.

40. Gaes GG. The effect of spatial and architectural housing variations on acute inmate morbidity indicators. Unpublished manuscript. Washington DC: Office of Research, Federal Prison System, 1982.

41. DeVito NJ, Goldacre B. Catalogue of bias: publication bias. BMJ Evid Based Med 2019;24:53-4.

42. Simpson PL, Simpson M, Butler T. Prison cell size and adverse health effects: potential mediating factors. Sydney: The Kirby Institute, UNSW Australia, Sydney, and Corrective Services NSW, 2016.

43. United States Court of Appeals. Eighth annual report on the council of environmental quality. Washington D.C., 1977.
44. McCorkle RC, Miethe TD, Drass KA. The roots of prison violence: a test of the deprivation, management, and "not-so-total" institution models. Crime \& Delinquency 1995;41:317-31.

45. Tartaro C. The impact of density on jail violence. J Crim Justice 2002;30:499-510.

46. Anson RH. Overcrowding and inmate fatalities. Int J Comp Appl Crim Justice 1984;8(1-2):93-9.

47. Bonta J, Kiem T. Institutional misconducts in a jail setting: preliminary findings and a note of caution. Crime and Justice 1978;6:175-8.

48. Atlas R. Violence in prison - architectural determinism: Florida State University, 1982.

49. Urrego J, Ko Al, da Silva Santos Carbone A, et al. The impact of ventilation and early diagnosis on tuberculosis transmission in brazilian prisons. Am J Trop Med Hyg 2015;93:739-46.

50. Ekland-Olson S, Barrick DM, Cohen LE. Prison overcrowding and disciplinary problems: an analysis of the texas prison system. J App/ Behav Sci 1983;19:163-76.

51. Megargee El. The association of population density, reduced space, and uncomfortable temperatures with misconduct in a prison community. Am J Community Psychol 1977;5:289-98.

52. McCain G, Cox VC, Paulus PB. The relationship between illness complaints and degree of crowding in a prison environment. Environ Behav 1976;8:283-90. 
Correction: Correction for Prison cell spatial density and infectious and communicable diseases: a systematic review

Simpson PL, Simpson M, Adily A, et al. Prison cell spatial density and infectious and communicable diseases: a systematic review. BMJ Open 2019;9:e026806. doi: 10.1136/ bmjopen-2018-026806

This article was previously published with errors. The authors noticed below errors:

- The acronym for the International Committee of the Red Cross presented in the last paragraph of the article (p. 8) should read ICRC and not ICPA.

- The guidelines stated in the last paragraph of the article (p. 8) should read ICRC guidelines.

- The initials of the reviewers who screened publications (p. 3) should read: PLS, AA and MS, TB.

Open access This is an open access article distributed in accordance with the Creative Commons Attribution Non Commercial (CC BY-NC 4.0) license, which permits others to distribute, remix, adapt, build upon this work non-commercially, and license their derivative works on different terms, provided the original work is properly cited, appropriate credit is given, any changes made indicated, and the use is non-commercial. See: http://creativecommons.org/licenses/by-nc/4.0/.

(c) Author(s) (or their employer(s)) 2020. Re-use permitted under CC BY-NC. No commercial re-use. See rights and permissions. Published by BMJ.

BMJ Open 2020;10:e026806corr1. doi:10.1136/bmjopen-2018-026806corr1

(A) Check for updates 